\title{
NITROGEN MANAGEMENT INTENSITY CHANGES IN FADN REGIONS OF POLAND IN 2002-2016
}

\author{
Adam Kleofas Berbec ${ }^{1}$, dr inz. and Jerzy Kopinski ${ }^{1}$, dr hab. \\ ${ }^{1}$ Institute of Soil Science and Plant Cultivation State Research Institute in Pulawy, Department of Systems and \\ Economics of Crop Production
}

\begin{abstract}
The paper presents trends of nitrogen management intensity changes. The comparative analysis of nitrogen management in the period 2002-2016 was performed at FADN regions of Poland level. It included comparisons of balances and efficiency of nitrogen utilization as well as rate and direction of nitrogen input and output in the agricultural production cycle. The structural and quantitative analysis of both sides of gross nitrogen balance provides information about the agricultural production as well as the direction and rate of changes . Although there was a visible, moderate intensification ( $A=$ type) of agricultural production in Poland, a significant differences between four regions of Poland were found. FADN region 785 (Pomorze i Mazury) had positive rating of agro-environmental aspects and nitrogen management. On the other hand, FADN region 790 (Wielkopolska i SSlask) was characterized by ineffective intensification of plant production (increased nitrogen inputs with low effect in nitrogen output).
\end{abstract}

Key words: regional development, gross nitrogen balance, intensification, extensification, nitrogen use efficiency.

JEL codes: Q15, Q51, Q56, R11, R15.

\section{Introduction}

Modern European agriculture draws more and more attention to the socially useful functions of the agriculture (reflecting the relationships between the value of the environment as a public good and the value of agricultural production conducted in this environment) (Fotyma M. et al., 2009; Prandecki K., Zegar J., 2014). In order to maintain the balance of ecosystems, it is necessary to optimize the use of nutrients in the agricultural production system, which means the recognition and control of nutrients inputs and outputs (Hatfield J.L., Douglas L.K., 1994; Kopinski J., 2017 a). Rational management of fertilizer components, including nitrogen, is part of the basic function of the agricultural objective - getting an income. It is achieved by maximizing the utility of agricultural activity by maximizing revenues and minimizing costs of involved means of production (Rembisz W, 2010). In terms of value, it has an impact on profitability, productivity, efficiency (economic and organizational) and competitiveness (Galecka A., 2017; Szymanska E., 2010; Zietara W., Zielinski M., 2012). In quantitative terms, it also has an impact on productivity assessment (technical efficiency) and intensity of agricultural production (Klepacki B., 1997), while also having an impact on environment (Jadczyszyn T., Kopinski J., 2013; Kopinski J., 2002, Pastuszak M. et al. 2014). Mineral fertilizer consumption, due to close correlation between the use of fertilizers (mainly nitrogen fertilizers) and the yields, is one of the most important measures of the intensity of agricultural production (Fotyma M. et al., 2009; Fotyma M. et al., 2012). Another evaluation measure of the intensity of production is the level of total nitrogen input in relation to the nitrogen output in the harvested yields and by-products, which takes into account all sources of nitrogen in the agricultural production system (Kopinski J., 2017b). Tendency and rate of changes in the level of nitrogen inputs allows to determine the nature of agricultural production (intensification, extensification) in terms of nitrogen management strategy. Determination of the tendency and rate of changes in the level of inputs (in terms of quantity) of nitrogen allows to determine the nature of agricultural production (intensification, extensification), in terms of managing this component (Kopinski J., 2018).

${ }^{1}$ Contacts to be added to the author, as a footnote at the bottom of the first page ( 6 point Verdana font) 
The basic source of information was the results of IUNG-PIB's (Institute of Soil Science and Plant Cultivation, State Research Institute in Pulawy) own research (Kopinski J., 2017a; 2017b) based on statistical data from the Central Statistical Office (GUS) (2002-2013; 2002-2015; 2003-2016; 20152016), Chief Inspectorate of Environmental Protection (CIEP) (2014) and KOBiZE (The National Centre for Emissions Management) (2016). The comparative analysis was carried out at the level of 4 FADN/RICA regions of Poland (785-Pomorze i Mazury; 790-Wielkopolska I Slask; 795-Mazowsze i Pomorze; 800-Malopolska i Pogorze)(Goraj L., 2000)(Figure 1). Averages for Poland were used as reference point. The analysis covered changes in balances (GNB) and efficiency of nitrogen utilization (EuN) in 2002-2016, based on the gross nitrogen balance in accordance with the standard proposed by the OECD and Eurostat (Kremer A.M., 2013; Kopinski J., 2017a). The determination of the character (type) of nitrogen management in regions was made on the basis of the difference in slope of trend lines $(\mathrm{a}, \mathrm{b})$ and gross nitrogen input $\left(\mathrm{TN}_{\mathrm{in}}\right)$ and output $\left(\mathrm{TN}_{\mathrm{out}}\right)$, in accordance to equation formulas and criteria:

$$
\begin{gathered}
\mathrm{GNB}=\mathrm{TN}_{\text {in }}-\mathrm{TN}_{\text {out }} ; \mathrm{EuN}=\mathrm{TN}_{\text {out }} / \mathrm{TN}_{\text {in }} \times 100 ; \\
y\left(\mathrm{TN}_{\mathrm{in}}\right)=\mathrm{ax}+\mathrm{m} ; \mathrm{y}\left(\mathrm{TN}_{\text {out }}\right)=\mathrm{bx}+\mathrm{k} \\
\mathrm{a}>0 \text { and } \mathrm{b}-\mathrm{a}>0 \text { effective intensification (rational), type A } \\
\mathrm{a}<0 \text { and } \mathrm{b}-\mathrm{a}>0 \text { efficient extensification (rational), type B } \\
\mathrm{a}>0 \text { and } \mathrm{b}-\mathrm{a}<0 \text { ineffective intensifying (irrational), type C } \\
\mathrm{a}<0 \text { and } \mathrm{b}-\mathrm{a}<0 \text { inefficient extensification (irrational), type D }
\end{gathered}
$$

where:

GNB - surplus balance (deficit) of gross nitrogen balance;

$\mathrm{TN}_{\text {in }}$ - total nitrogen inputs;

$\mathrm{TN}_{\text {out }}$ - total nitrogen outputs;

EuN - efficiency of nitrogen use (utilization).

To assess the strength of observed tendencies, an analysis of the distribution of the value of the feature (differences in the slope of the trend line (b-a)) was used, where:

$-0.35>(b-a)>1.1$ strong tendency $(+)$;

$-0.35 \leq(b-a) \leq 1,1$ weak tendency $(=)$.

More detailed methodology of the research was presented in previous author's publication about trends of change in agricultural nitrogen management (Kopinski J., 2018).

The major objective of the study was to assess trends of agricultural intensity changes in Poland over time. Tendencies and rate of changes of agricultural nitrogen management intensity in 4 FADN/RICA regions of Poland were assessed on a basis of the results of the gross nitrogen balance in the period of 2002-2016. 


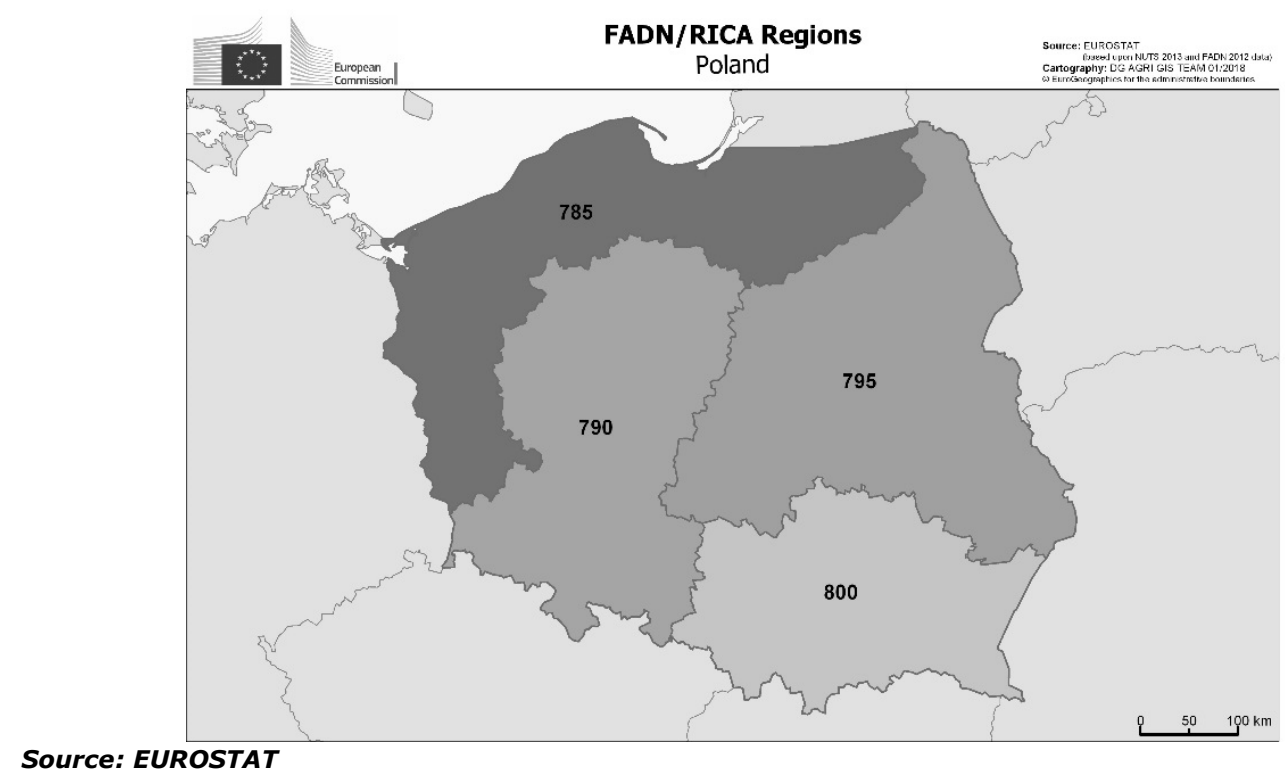

Fig. 1. FADN/RICA regions of Poland

\section{Research results and discussion}

The diversified (quantitative) structure of nitrogen inputs and outputs from agricultural land is a confirmation of the existing large regional differentiation of Polish agriculture (Figure 2). This quantitative and structural diversification of gross nitrogen balances results from very large differences in natural conditions, production intensity and productivity of agricultural land, as well as of the differences in the organizational and production potential of individual regions of Poland (Fotyma M. et al., 2009; Kopinski J., 2017a). The analysis shows that the highest management intensity (nitrogen turnover) was observed in the region of "Wielkopolska and Slask" (almost $250 \mathrm{~kg}$ $\mathrm{N} \bullet \mathrm{ha}^{-1} \mathrm{AL}$ ). "Malopolska and Pogorze" region, had the lowest management intensity (volume of turnover $170 \mathrm{~kg} \mathrm{~N} \bullet \mathrm{ha}^{-1} \mathrm{AL}$ ). In recent years (2014-2016) mineral fertilizers has been the dominating position on the nitrogen revenue side in all regions of Poland ( $57.4 \%$ on average). However, in the structure of the balance, the collection of nitrogen with plants yields dominates in all regions (Figure 2). Nitrogen outputs structure depends not only on the land use structure (UAA), but also on its productivity. It also reflects the production orientation (degree of specialization) of individual regions.

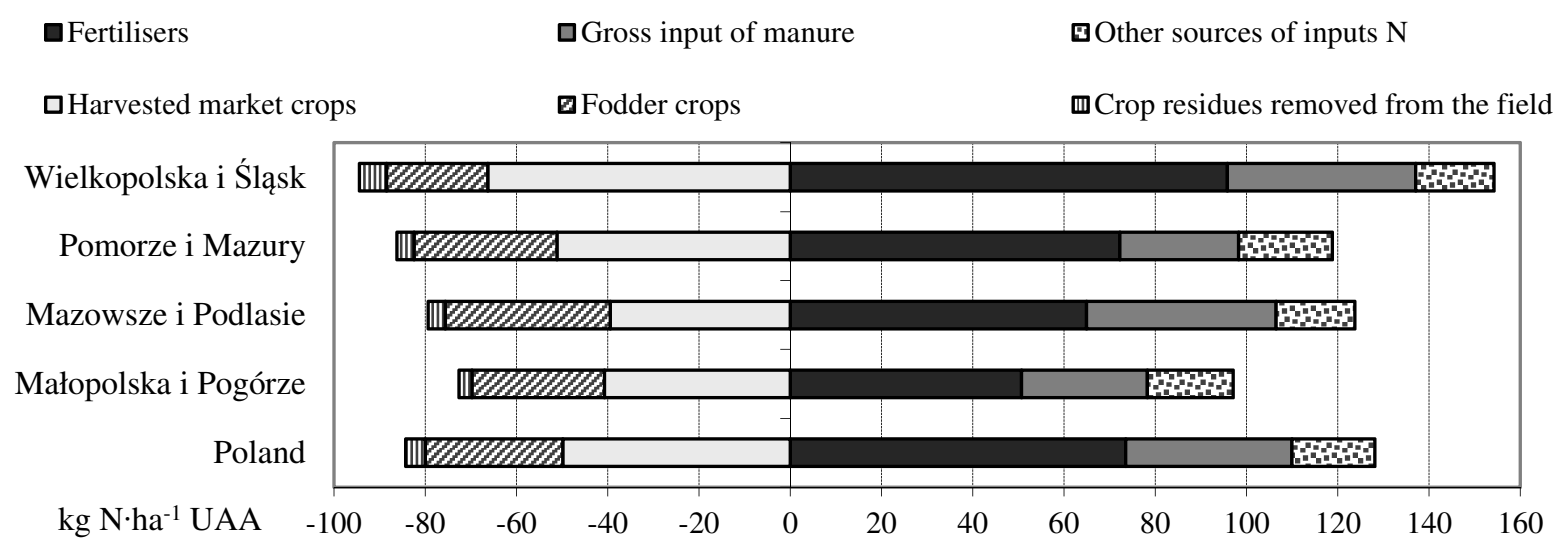

Source: author's study based on basic CSO, CIEP and NCEM data

Fig. 2. The quantitative structure of various inputs and outputs sources of gross nitrogen budget in Polish FADN regions in 2014-2016 years (kg N ha-1 UAA) 
Quantitative and structural changes of sources of nitrogen inputs and outputs leads to the changes in current gross nitrogen balances and the efficiency of using this component (Table 1). "Wielkopolska and Silesia" region had highest gross nitrogen balance surplus (60 kg $\cdot \mathrm{ha}^{-1}$ UAA), when compared to averages for Poland. This is expected to have a negative impact on the environment (Kopinski J., 2017a). In the years of 2014-2016, there was a significant quantitative reduction in the balance surplus of gross nitrogen balance (by approx. $20 \mathrm{~kg} \cdot \mathrm{ha}^{-1} \mathrm{UAA}$ ) in the region of "Pomerania and Masuria" when compared to 2002-2004. Also there was a visible improvement of efficiency of nitrogen utilization in all regions, although of a different degree (Table 1). The largest increases of nitrogen utilization efficiency were recorded in the region of "Pomerania and Masuria"(20.6\%). The diversification of the efficiency of nitrogen utilization in different regions results in different environmental impact of agriculture in tested regions. This is both due to organizational and production changes, including intensifying processes of specialization and concentration of agricultural production, as well as natural conditions of specific regions (Pastuszak M. et al., 2014].

The analysis of the directions and rate of changes in the nitrogen inputs in the cycle of agricultural production in 2002-2016 (Table 1) shows that in all FADN/RICA regions of Poland intensification of agricultural production (mainly type $A$, but also type $C$ ) took place. The increasing use of nitrogen mineral fertilizers was the main factor behind the intensification. "Malopolska and Pogorze" region was to the least extent of this intensification. On the other hand, "Wielkopolska and Slask" region was characterized by the most, statistically significant, ineffective intensifying of agricultural nitrogen management (Type $\mathrm{C}+$ ). The region had significantly higher rate of nitrogen input intensification, which led to the increase in the nitrogen gross balance, with just slight improvement in efficiency. This could have serious environmental consequences, especially in regions that also had adverse environmental indicators in previous years, e.g in "Wielkopolska and Slask" region (Fotyma M. et al., 2012; Kopinski J., 2017a). This is because environmental risk of nitrogenous nutrients (nitrates) leaking to groundwater are stronger on light, sandy soils of low water capacity, which are common to Poland. This was confirmed by the results of monitoring studies carried out in the Wielkopolskie Voivodeship, in the area of which high concentrations of nitrates were found in soil water and groundwater (Jadczyszyn T., Kopinski J., 2013).

Among other FADN/RICA regions in Poland, "Mazowsze i Podlasie" had rather poor, but still significant increase of rate of rational, effective intensification of land productivity (type $A=$ ). The region in which there was a significant (strong) increase in efficiency through a significant increase in nitrogen output with little or No increase in nitrogen inputs, was "Pomorze i Mazury" region (type A+). Moreover, "Pomorze i Mazury" had a very positive agro-environmental assessment results (low balance and high efficiency of nitrogen utilization), when compared to the averages for Poland (Table 1). A process of rationalization of plant production was visible in regions that had nitrogen management of type A+ (strong, effective intensification of production), like "Pomorze i Mazury". This was due to better management strategy, mostly effective use of organizational factors (nonfertilizer means of production).

\section{Conclusions}

The structural and quantitative analysis of both sides of the gross nitrogen balance (inputs and outputs) provides information on management of agricultural production in the aspect of nitrogen fertilization. The analysis of relationship and rate of change in nitrogen inputs and its effects (nitrogen 
outputs) enables the assessment of the nature(intensification, extensification) and type of plant production. On a national scale, since 2002, moderate intensification (type $A=$ ) of plant production is visible. Nevertheless, there are significant differences between FADN/RICA regions of Poland, both in current state and the direction of changes. "Pomorze i Mazury" (type $A+$ ), "Malopolska and Pogorze" (type $\mathrm{A}=$ ) and "Mazowsze and Podlasie" (type $\mathrm{A}=$ ) regions were characterized by, to a certain degree, rational intensification of plant production, while "Wielkopolska and Silesia" (type C + ), was the region where the intensification of plant production was not justified by the increased effects (nitrogen outputs - mostly crop yields). In terms of agri-environmental assessment and nitrogen management practices, „Pomorze i Mazury” region was characterized by low-intensity, but highly effective plant (agricultural) production.

\section{Acknowledgments}

The presented study was carried out as part of 2.1 task of Multiannual Programme of Institute of Soil Science and Plant Cultivation, State Research Institute in Puławy, Poland.

Table 1.

\section{Characteristics of the resulting elements of the gross nitrogen balance as well as trends and types of nitrogen management in the Polish FADN regions in 2002-2016}

\begin{tabular}{|c|c|c|c|c|c|c|c|c|}
\hline \multirow[b]{2}{*}{$\begin{array}{l}\text { FADN } \\
\text { regions }\end{array}$} & \multicolumn{2}{|c|}{$\begin{array}{c}\text { Surplus of } \\
\text { gross nitrogen } \\
\text { balance GNB } \\
\text { kg-ha-1 UAA }\end{array}$} & \multicolumn{2}{|c|}{$\begin{array}{c}\text { Efficiency of } \mathbf{N} \\
\text { use UeN } \\
(\%, \text { p.p. })\end{array}$} & \multicolumn{2}{|c|}{$\begin{array}{c}\text { Equation of trend } R 2 \\
\text { Period of 2002-2016 } \\
\text { years }\end{array}$} & \multirow{2}{*}{$\begin{array}{c}\text { Differenc } \\
\text { e in trend } \\
\text { inclinatio } \\
n \\
\text { between } \\
\text { outputs } \\
\text { and } \\
\text { inputs } \\
b-a\end{array}$} & \multirow[b]{2}{*}{$\begin{array}{c}\text { Type of } \\
\text { nitrogen } \\
\text { manageme } \\
\text { nt }\end{array}$} \\
\hline & $\begin{array}{c}2014 \\
- \\
2016 \\
\text { years }\end{array}$ & $\begin{array}{c}\text { Change* } \\
*\end{array}$ & $\begin{array}{c}2014 \\
- \\
2016 \\
\text { years }\end{array}$ & $\begin{array}{c}\text { Change* } \\
*\end{array}$ & $\begin{array}{l}\text { total } \\
\text { nitrogen } \\
\text { inputs }\end{array}$ & $\begin{array}{c}\text { total } \\
\text { nitrogen } \\
\text { outputs } \\
\\
y(\text { TNout }) \\
=b x+k\end{array}$ & & \\
\hline $\begin{array}{l}\text { Pomorze i } \\
\text { Mazury }\end{array}$ & 31,8 & $-19,6$ & 73,0 & 20,6 & $\begin{array}{c}y=1,1 x+ \\
112,7 \quad 0,2 \\
2\end{array}$ & $\begin{array}{c}y= \\
2,5 x+ \\
51,5 \\
0,84 *\end{array}$ & 1,48 & $A+$ \\
\hline $\begin{array}{l}\text { Wielkopolsk } \\
\text { a i Slask }\end{array}$ & 59,9 & 6,3 & 61,2 & 2,4 & $\begin{array}{c}y=2,1 x+ \\
133,2 \\
0,55^{*}\end{array}$ & $\begin{array}{c}y= \\
1,6 x+ \\
72,1 \\
0,56 *\end{array}$ & $-0,51$ & $C+$ \\
\hline $\begin{array}{l}\text { Mazowsze i } \\
\text { Podlasie }\end{array}$ & 44,4 & $-2,9$ & 64,1 & 7,7 & $\begin{array}{c}y=1,2 x+ \\
111,5 \\
0,40^{*}\end{array}$ & $\begin{array}{c}y= \\
1,6 x+ \\
58,3 \\
0,66^{*}\end{array}$ & 0,42 & $A=$ \\
\hline $\begin{array}{l}\text { Malopolska } \\
\text { i Pogorze }\end{array}$ & 24,5 & $-8,0$ & 74,8 & 10,3 & $\begin{array}{c}y=0,3 x+ \\
94,4 \\
0,10\end{array}$ & $\begin{array}{c}y= \\
1,1 x+ \\
5745 \\
0,61^{*}\end{array}$ & 0,81 & $A=$ \\
\hline POLAND & 43,9 & $-3,8$ & 65,8 & 8,5 & $\begin{array}{c}y=1,4 x+ \\
114,5 \\
0,49^{*}\end{array}$ & $\begin{array}{c}y= \\
1,8 x+ \\
60,3 \\
0,73^{*}\end{array}$ & 0,36 & $\mathbf{A}=$ \\
\hline
\end{tabular}

** difference absolute values between of 2014-2016 and 2002-2004 years

Source: authors; calculations based on CSO, CIEP and NCEM data 


\section{Bibliography}

1. Hatfield Jerry L., Douglas L. Karlen. 1994. Sustainable Agriculture Systems. Florida: Lewis Publishers.

2. Fotyma Mariusz, Janusz Igras, Jerzy Kopinski. 2012. Nitrogen Utilization and Diffuse Losses in Agricultural Crop Production [In] Contribution of Polish agriculture to emission of nitrogen and phosphorus compounds to the Baltic Sea, ed. Janusz Igras, Marianna Pastuszak, 109-159. Gdynia-Pulawy: NMFRI, ISSPC-SRI, FRI.

3. Fotyma Mariusz, Janusz Igras, Jerzy Kopinski. 2009. Produkcyjne i srodowiskowe uwarunkowania gospodarki nawozowej w Polsce (Production and environmental conditions of fertilizer management in Poland). Studia i Raporty IUNG-PIB 14: 187-206.

4. Galecka Agnieszka. 2017. Efektywnosc gospodarstw rolnych w Polsce w latach 2012-2015 w zaleznosci od ich wielkosci ekonomicznej (Efficiency of agricultural farms in Poland in 2012-2015 depending on their economic size). Roczniki Naukowe SERiA 19(5): 65-71, doi: 10.5604/01.3001.0010.6207.

5. GIOS. 2014. Stan srodowiska w Polsce. Raport 2014 (The state of the environment in Poland. Report 2014). Warszawa: GIOS Biblioteka Monitoringu Srodowiska.

6. Goraj Lech. 2000. Siec danych rachunkowosci gospodarstw rolnych w Unii Europejskiej. Ed. Foundation of Assistance Programmes for Agriculture. Warszawa, pp. 69.

7. GUS. 2003-2017. Produkcja upraw rolnych i ogrodniczych w 2002...2016 roku (Production of agricultural and horticultural crops in 2002 ... 2016). Warszawa: GUS.

8. GUS. 2002-2016. Srodki produkcji w rolnictwie w roku gospodarczym 2001...2015/2016 (Means of production in agriculture in the 2001 ... 2015/2016 farming year). Warszawa: GUS.

9. GUS. 2002-2013. Uzytkowanie gruntow, powierzchnia zasiewow i poglowie zwierzat gospodarskich w 2002 ... 2013 roku (Land use, sown area and livestock stocks in 2002 ... 2013). Warszawa: GUS.

10. GUS. 2015-2017. Zwierzeta gospodarskie w 2014 ... 2016 roku (Livestock in 2014 ... 2016). Warszawa: GUS.

11. Jadczyszyn Tamara, Jerzy Kopinski. 2013. Nawozenie azotem w Polsce - aspekt produkcyjny i srodowiskowy (Nitrogen fertilization in Poland - production and environmental aspect). Studia i Raporty IUNG-PIB 34(8): 125-143.

12. Klepacki Bogdan. 1997. Wybrane pojecia z zakresu organizacji gospodarstw, produkcji i pracy w rolnictwie (Selected concepts from the organization of farms, production and work in agriculture). Warszawa: Wydawnictwo SGGW.

13. KOBiZE. 2016. Poland's National Inventory Reports 2016. Warszawa: IOS-PIB.

14. Kopinski Jerzy. 2017a. Bilans azotu brutto - agrosrodowiskowy wskaznik oddzialywania rolnictwa na srodowisko. Opis metodyki, omowienie wynikow bilansu na poziomie NUTS-0, NUTS-2 (Gross nitrogen balances (budget) - agrienvironmental indicators of changes of agricultural production. Methodology and the results of balances on the level NUTS-0 (Poland), NUTS-2 (voivodeships)). Pulawy: Wydawnictwo IUNG-PIB Monografie i rozprawy naukowe, 55, ss. 111.

15. Kopinski Jerzy. 2017b. Ocena zmian efektywnosci wykorzystania azotu w produkcji rolniczej Polski (Evaluation of changes in the efficiency of nitrogen utilization in agricultural production of Poland). Roczniki Naukowe SERiA 19(1): 85-91, doi: 10.5604/01.3001.0009.8344.

16. Kopinski Jerzy. 2018. Tendencje zmian intensywnosci gospodarowania azotem w regionach Polski (Tendencies of changing intensity of nitrogen management in the Polish regions). Roczniki Naukowe SERiA 20(1): 81-87, doi: 10.5604/01.3001.0011.7232.

17. Kopinski Jerzy. 2002. Porownanie wskaznikow rozwoju zrownowazonego gospodarstw o roznej intensywnosci produkcji rolnej (Comparison of the parameters of sustainable development of farms with different intensity of agricultural production). Roczniki Nauk Rolniczych. Seria G, 89(2): 66-72.

18. Kremer Anne Miek. 2013. Nutrient Budgets EU-27, Norway, Switzerland. Methodology and Handbook. ver. 1.02. Luxembourg: Eurostat/OECD. EC Eurostat. http://ec.europa.eu/eurostat/cache/metadata/Annexes/aei_pr_gnb_esms_an1.pdf, dostep: 17/05/2013.

19. Pastuszak Marianna, Tomasz Kowalkowski, Jerzy Kopinski, Jaroslaw Stalenga, Damian Panasiuk. 2014. Impact of forecasted changes in Polish economy (2015 and 2020) on nutrient emission into the river basins. Science of the Total Environment, 493: 32-43, doi: 10.1016/j.scitotenv.2014.05.124.

20. Prandecki Konrad. 2015. Zagrozenia srodowiskowe pochodzenia rolniczego jako skutek efektow zewnetrznych. [W] Efekty zewnetrzne i dobra wspolne w rolnictwie - identyfikacja problemu (Environmental threats of agricultural origin as a result of external effects [In] External effects and common values in agriculture - problem identification), red. Konrad Prandecki, 68-89, Warszawa: Monografie PW IERigZ-PIB.

21. Rembisz Wlodzimierz. 2010. Kwestie efektywnosci, cen i dochodow producentow rolnych. [W] Agroekonomia w warunkach rynkowych. Problemy i wyzwania (Productivity, prices and farm producers' incomes issues [In] Agroeconomy in market conditions. Problems and challenges), red. Aleksander Grzelak, Agnieszka Sapa, 289-302, Poznan: Zeszyty Naukowe UE, 150.

22. Szymanska Elzbieta. 2010. Efektywnosc przedsiebiorstw - definiowanie i pomiar (Enterprise effectiveness defining and measurement). Roczniki Nauk Rolniczych. Seria G 97(2): 152-164.

23.Zegar Jozef. 2014. Konkurencyjnosc rolnictwa zrownowazonego. Synteza. (Competitiveness of sustainable agriculture. Synthesis). Warszawa: Monografie PW IERiGZ-PIB, 142.1.

Zietara Wojciech, Marek Zielinski. 2012. Efektywnosc i konkurencyjnosc polskich gospodarstw rolniczych nastawionych na produkcje roslinna (The effectiveness and competitiveness of polish crop-oriented farms). Zagadnienia Ekonomiki Rolnej 1: 40-61. 